Original Article

\title{
PRETENT STATUS AND PROBLEMS WITH THE METHODS FOR TESTING IMMUNOTOXICITY
}

\author{
Taketoshi Saijo \\ Drug Safety Research Laboratories, Pharmaceutical Development Division, Pharmaceutical Group, \\ Takeda Chemical Industries, LTD.
}

Hiroaki Miyajima

Shin Nippon Biomedical Laboratories, LTD.

\begin{abstract}
Immunotoxicology has become a very important field because of the immunological adverse effects of various cytokines (IL-2 and IFN $\alpha$, etc.) and biological response modifiers in addition to the immunosuppression caused by steroid hormones and anticancer agents and drug (antibiotic)-induced allergies. The adverse effects include the development of infectious diseases or various cancers due to immunosuppression and the occurrence of allergies or autoimmunity due to immunopotentiation. Studies to establish testing guidelines were done worldwide using immunosuppressants (azathioprine and cyclosporin A), and the most suitable marker or test system to detect immunotoxicity of xenobiotics was explored. Moreover, the necessity of immunotoxicity studies is stressed in "Redbood II" (FDA, draft ; 1993). In experiments on thymus toxicity in the rat, the following data were obtained. The weight of the thymus increased from birth until 8 weeks of age and then decreased gradually. The weight was also decreased by stress induced by factors such as fasting, the attachment of an Elizabeth collar, etc. and the administration of cyclophosphamide (immunosuppressant). This drug caused degenerative changes in the thymus, spleen, and bone marrow and inhibited the plaque forming cell response to sheep red blood cells in rats. TGP-3 (human recombinant interleukin 2) caused fever via the production of interleukin $1 \beta$ and increased the number of eosinophils.

When the immune system was suppressed by exposure to 2,3,7,8-tetrachlorodibenzo-p-dioxin (TCDD) or chronic administration of an immunosuppressant (cyclophosphamide), the susceptibility to infectious diseases and tumor formation was increased. On the other hand, when the action of the immune system was potentiated by the repeated administration of an immunomodulator (antirheumatic agent), autoimmune diseases rarely occurred. The importance of immunotoxicology and future directions for immunotoxicity testing are discussed in this paper. (J Toxicol Pathol $8: 245 \sim 256,1995$ )
\end{abstract}

Key words : Immunotoxicology, Xenobiotics, Stress, Environmental pollution

\section{Introduction}

The immune system is comprised of many kinds of cells (e.g., macrophages, $T$ and $B$ lymphocytes and natural killer cells) and processes (e.g., antigen recognition and processing ; cellular

\section{西条武俊 宮真宏彰}

Accepted for publication: March 2, 1995

Mailing address: Taketoshi Saijo, Drug Safety Research Laboratories, Pharmaceutical Development Division, Takeda Chemical Industries, LTD, 6-10-1, Himuro-cho, Takatsuki, Osaka 569, Japan interactions involving cooperation, regulation and amplification; cell activation, proliferation and differentiation; and mediator production). This system protects the body from invasion by xenobiotics such as microorganisms (bacteria/viruses) and air pollutants $\left(\mathrm{NO}_{2}\right.$ and $\left.\mathrm{SO}_{2}\right)$ by neutralization, inactivation or elimination. The sensitivity of the immune system to a xenobiotic depends on the nature of the xenobiotic and its susceptibility to each component of the system. Immunotoxicity is caused when the system is impaired directly or indirectly, and immunomodulation (i.e., sup- 
pression or potentiation), allergies, and autoimmune diseases might be induced as a consequence of the damage.

Immunotoxicology was defined as a discipline concerned with the study of the events that can lead to undesired effects as a result of the interaction of xenobiotics with the immune system at the International Seminar on the Immunological System as a Target for Toxic Damage (Luxembourg, 1984). These undesired events may result as a consequence of : 1) a direct and/or indirect effect of the xenobiotic (and/or its biotransformation product) on the immune system, or 2) an immunologically-based host response to the compound and/or its metabolite(s) or host antigen modified by the compound or its metabolite(s).

The immunotoxicities of various xenobiotics are indicated in Table 1. Among these xenobiotics, environmental chemicals such as dioxin and organotin are important, because they pose a serious threat to human health, and we are seeing the development of a new field of study, environmental immunology.

In Europe and the USA, immunological testing methods to detect immunotoxicity or reliably assess the risk of immunotoxicity have been proposed. One of them is outlined in Table $2^{2}$. This method is composed of two parts, that is, Tier I and II. Tier I consists of examination of lymphoid organs (e.g., weights and histology), hematological studies and tests to determine general immune function (PFC response and natural killer cell activity). Tier II includes evaluation of effector $\mathrm{T}$ cell function (i.e., delayed type hypersensitivity or cytotoxic $\mathrm{T}$ cell response), quantification of splenic B cells, $T$ cells, and $T$ cell subsets, and host resistance. Evaluation of immunotoxicity testing using azathioprine and cyclosporin $\mathrm{A}$ was done as the International Collaborative Immunotoxicity Study. Harmonization among Japan, Europe, and the USA has been attempted with reference to the results of these studies. In this paper, the data obtained in our laboratories is shown, and the importance of immunotoxicology is discussed making reference to the findings obtained in other laboratories.

\section{Experiments on immunotoxicity}

The following experiments were done.

1) Effects of various stress factors and aging on the weights of the thymus, spleen, and adrenals

Table 1. Immunotoxicity of Xenobiotics

\begin{tabular}{|c|c|c|}
\hline Agent & Mechanism & Organ system \\
\hline Steroid hormones & $\begin{array}{l}\text { Immunosuppression (estrogens, } \\
\text { via estrogen receptors) } \\
\text { Immunostimulation (androgens) }\end{array}$ & $\begin{aligned} \text { Thymus : } & \text { cortical depletion, } \\
& \text { apoptosis, } \\
& \text { phagocytosis }\end{aligned}$ \\
\hline $\begin{array}{l}\text { Halogenated aromatic } \\
\text { hydrocarbons }\end{array}$ & $\begin{array}{l}\text { Immunosuppression via } \\
A h \text {-receptors }\end{array}$ & Thymus : cortical depletion \\
\hline Organotin compounds & $\begin{array}{l}\text { Immunosuppression, cytotoxic } \\
\text { anti-proliferation }\end{array}$ & Thymus : cortical depletion \\
\hline Heavy metals & $\begin{array}{l}\text { Immunosuppression, } \\
\text { immunomodulation/hypersen- } \\
\text { sitivity }\end{array}$ & $\begin{array}{l}\text { Multiple sites, dependent on the } \\
\text { target of hypersensitivity }\end{array}$ \\
\hline Cyclosporin A & $\begin{array}{l}\text { Immunosuppression, via cyclo- } \\
\text { philin/carcineurin complex } \\
\text { Autoimmunity, pseudo-graft-ver- } \\
\text { sus-host reaction }\end{array}$ & $\begin{array}{l}\text { Kidney, tubular necrosis, inter- } \\
\text { stitial fibrosis } \\
\text { Thymus : medullary reduction }\end{array}$ \\
\hline UV-B light & $\begin{array}{l}\text { Immunosuppression, induction of } \\
\text { suppressor cells } \\
\text { Carcinogenesis }\end{array}$ & $\begin{array}{l}\text { Skin, decrease of Langerhans cells } \\
\text { Non-melanoma skin tumors }\end{array}$ \\
\hline $\begin{array}{l}\text { Oxidant air } \\
\text { pollutants }\end{array}$ & Immunosuppression & $\begin{array}{l}\text { Lung: Influx of macrophages } \\
\left(0_{3}\right) \text {, pneumocyte alteration }\end{array}$ \\
\hline
\end{tabular}


Table 2. Panel for Detecting Immune Alterations Following Chemical or Drug Exposure in Rodents ${ }^{\mathrm{a}}$

\begin{tabular}{|c|c|}
\hline Parameter & Procedures \\
\hline \multicolumn{2}{|l|}{ SCREEN (Tier I) } \\
\hline Immunopathology & $\begin{array}{l}\text { - Hematology : Complete blood count and differential } \\
\text { - Weight : Body, spleen, thymus, kidney, liver } \\
\text { - Cellularity: Spleen } \\
\text { - Histology : Spleen, thymus, lymph node }\end{array}$ \\
\hline Humoral immunity & $\begin{array}{l}\text { - Enumerate IgM antibody plaque-forming cells to } \mathrm{T} \text {-dependent } \\
\text { antigen (SRBC) } \\
\text { - LPS mitogen response }\end{array}$ \\
\hline $\begin{array}{l}\text { Cell-mediated } \\
\text { immunity }\end{array}$ & $\begin{array}{l}\text { - Lymphocyte blastogenesis in response to mitogens (Con A) } \\
\text { - Mixed leukocyte response against allogeneic leukocytes (MLR) }\end{array}$ \\
\hline Nonspecific immunity & - Natural killer (NK) cell activity \\
\hline COMPREHENSIVE & \\
\hline Immunopathology & - Quantitation of splenic B and $T$ cell numbers \\
\hline $\begin{array}{l}\text { Humoral-mediated } \\
\text { immunity }\end{array}$ & - Enumeration of IgG antibody response to SRBC \\
\hline $\begin{array}{l}\text { Cell-mediated } \\
\text { immunity }\end{array}$ & $\begin{array}{l}\text { - Cytotoxic T lymphocyte (CTL) cytolysis } \\
\text { - Delayed hypersensitivity response (DHR) }\end{array}$ \\
\hline $\begin{array}{l}\text { Nonspecific } \\
\text { immunity }\end{array}$ & $\begin{array}{l}\text { - Macrophage function-quantitation of resident peritoneal cells and } \\
\text { phagocytic ability (basal and activated by MAF) }\end{array}$ \\
\hline $\begin{array}{l}\text { Host resistance } \\
\text { challenge models } \\
\text { (endpoints) }\end{array}$ & $\begin{array}{l}\text { - Syngeneic tumor cells } \\
\text { - PYB6 sarcoma (tumor incidence) } \\
\text { - B16F10 melanoma (lung burden) } \\
\text { - Bacterial models : Listeria monocytogenes (mortality); } \\
\text { Streptococcus species (mortality) } \\
\text { Viral models: Influenza (mortality); } \\
\text { Parasite models: Plasmodium yoelii (Parasitaemia) }\end{array}$ \\
\hline
\end{tabular}

- The testing panel was developed using B6C3Fl mice.

- For any particular chemical test only two or three host resistance models are selected for examination.

2) Effects of cyclophosphamide on the immunological organs and plaque forming cell response to sheep red blood cells (SRBC) in rats

3) Capability of TGP-3 (human recombinant interleukin 2) to induce IL-1 $\beta$ production and to enhance the proliferation of eosinophils

1) Effects of various stress factors and aging on the weights of the thymus, spleen, and adrenals

The following operations or conditions are used in ordinary toxicity studies.

(1) Fasting for one day, bleeding at autopsy, (2) attachment of an Elizabeth collar around the neck, (3) restraining (support) for i.v. injection, (4) caged under crowded or solitary conditions, and (5) deprivation of water. The effects of these operations and conditions on the immunological organs in the rat were studied by examining changes in the weights of the thymus, adrenals, and spleen.

\section{Various stress factors}

Both sexes of F344/Jcl ( 5 and 7 wks old) or male Jcl : Wistar rats (4 wks old) were used in these experiments. The conditions of various experiments were as follows.

(1) Fasting and bleeding

Rats were fasted for one day before bleeding.

(2) Attachment of an Elizabeth collar around the neck

An Elizabeth collar made of plastic (diameter, $60 \mathrm{~mm}$; weight, $3.98 \mathrm{~g}$ ) was put around the neck 
for 2 weeks before bleeding.

(3) Restraining for i.v. injection

Rats were restrained for $5 \mathrm{~min}$ per day for 2 weeks before bleeding. tions

(4) Caged under crowded or solitary condi-

Four rats were caged together for crowded conditions, and one rat was caged alone for solitary conditions.

(5) Deprivation of water

Rats were deprived of water for one day at 5 weeks of age thereafter were given water until bleeding at 7 weeks of age.

The data are summarized in Fig 1. Fasting was found to be the strongest stress factor, because the absolute weight of the adrenals was increased by about $30 \%$. Moreover, in the fasted rats, the absolute weight of the thymus and spleen was decreased by 13 and 19\%, respectively. The attachmet of an Elizabeth collar induces mild stress, because a significant decrease in the thymus weight and a moderate increase in the adrenal weight were observed. Bleeding decreased the weight of the adrenals, but this may be due to merely depletion of blood. Although the other treatments induced some effects, they were small or not significant.

Therefore, we need to keep in mind that some routine treatments have an effect (stress) on lymphoid tissue (thymus and spleen) and the adrenals when the results of toxicity tests are

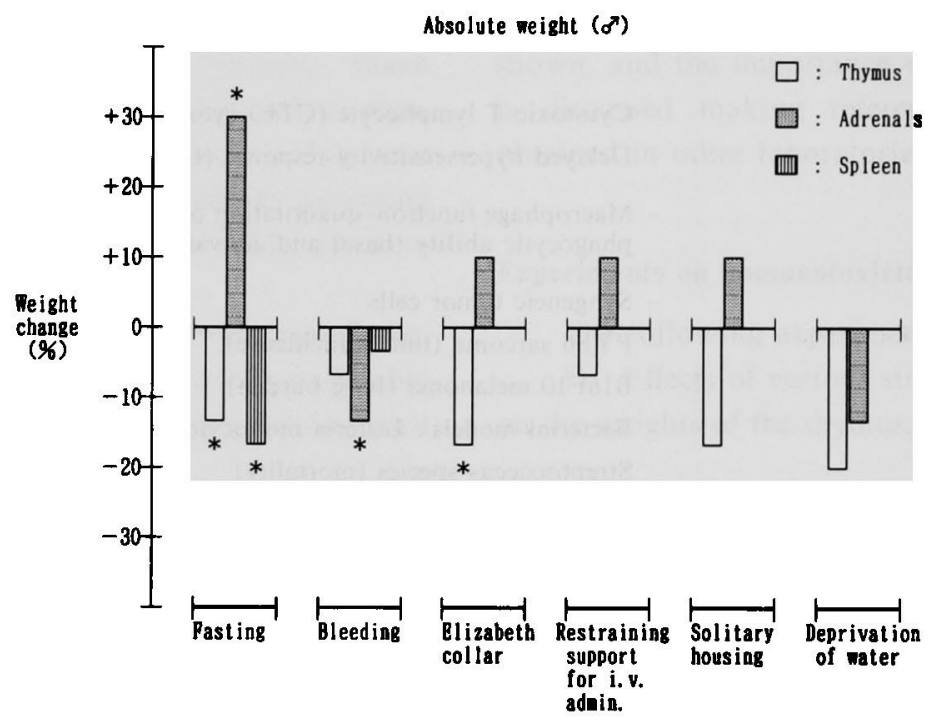

Fig. 1. Effect of various operations on the weight of thymus, adrenals, and spleen in the rat. ${ }^{*} \mathrm{p}<0.05, \mathrm{~N}=5$
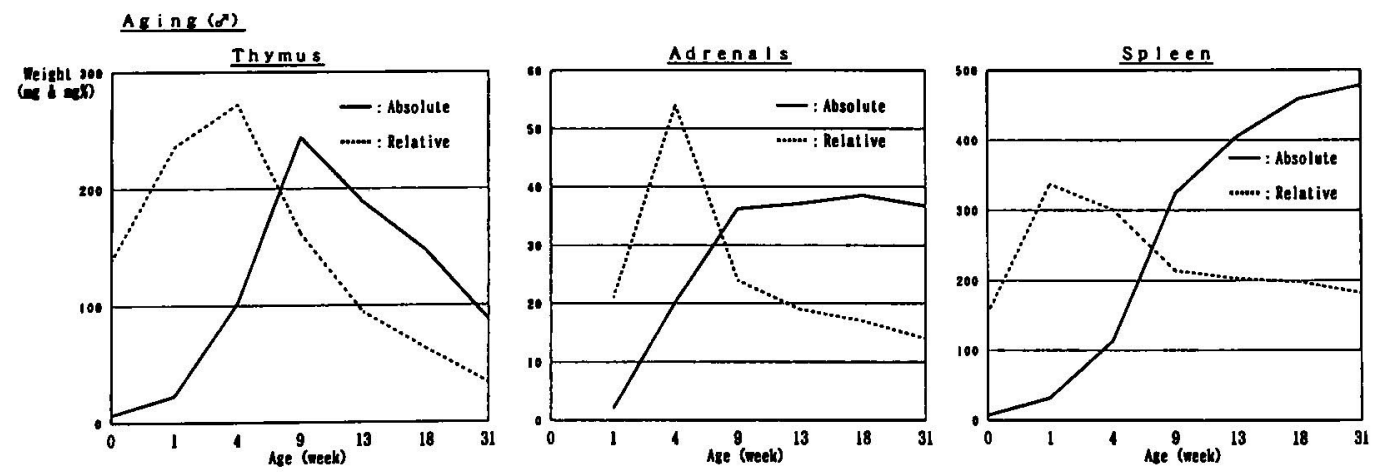

Fig. 2. Effect of aging on the weight of the thymus, adrenals, and spleen in the rat. Each point represents the mean of 5 rats. 
assessed.

\section{Change in thymus weight with aging}

This experiment was done to investigate the change in thymus weight with aging under normal laboratory conditions. Both sexes of F344/Jcl rats were used. The rats were killed from 0 to 31 weeks after birth. They were autopsied, and the thymus, adrenals, and spleen were weighed. The results for male rats are shown in Fig. 2. The absolute weight of the thymus is the greatest at the age of 8 weeks, and then it gradually decreases. Female rats showed a similar pattern (data not shown). The changes in adrenals and spleen weight are also shown in the Figure. The pattern of changes in the absolute weight of these organs was different from that for changes in the thymus weight.

The data on the changes in the thymus weight with aging were similar to those obtained previously $^{2}$. The decrease in thymus weight after the age of 8 weeks may be due to partly changes in sex hormone levels ${ }^{3}$; however, the details are not known at this time.

2) Effects of cyclophosphamide on the immunological organs and plaque forming cell response (PFC) to $S R B C$ in rats

Effects of cyclophosphamide (Cy) on the immunological organs (thymus, spleen, and bone marrow) and PFC response were studied in male F344/Jcl rats.

First, $C y$ at doses of 3 and $10 \mathrm{mg} / \mathrm{kg} /$ day was given intraperitoneally for 7 days. The effect on immunological organs was investigated histopathologically. No changes in body weight were observed in either dosing group (Fig. 3). The absolute weights of the thymus and spleen decreased dose-dependently. Upon histopathological examination, atrophy with lymphocyte depletion in the cortex was observed in the thymus (Fig. 4). Atrophy in the white pulp was seen in the spleen. Moreover, hypocellularity was observed in the bone marrow.

Second, the effect of Cy on PFC response was examined using rats'. Rats were immunized by intravenous injection of Sheep Red Blood Cells (SRBC). Cy at doses of 3,10 , and $30 \mathrm{mg} / \mathrm{kg}$ was given orally once immediately after the immunization. The PFC response was measured according to the method of Cunningham and Szenbergh ${ }^{5}$. The PFC response was inhibited dose-dependently (Table 3).

Upon histopathological examination, $\mathrm{Cy}$ was found to cause degenerative changes in the thymus, spleen and bone marrow. In the spleen, the atrophic change was stronger in the $B$ cell-dependent region than in the $T$ cell-dependent one, confirming that $B$ cells are more sensitive to $\mathrm{Cy}$ than $T$ cells ${ }^{6,7}$. Furthermore, $C y$ inhibited the PFC response to SRBC in the rat. These results are clearly related to the above mentioned histopathological observations. The fact that $\mathrm{Cy}$ even at a single dose of $3 \mathrm{mg} / \mathrm{kg}$ showed a significant inhibitory effect on the PFC response suggests that the PFC assay is an appropriate method to detect functional changes in the immune
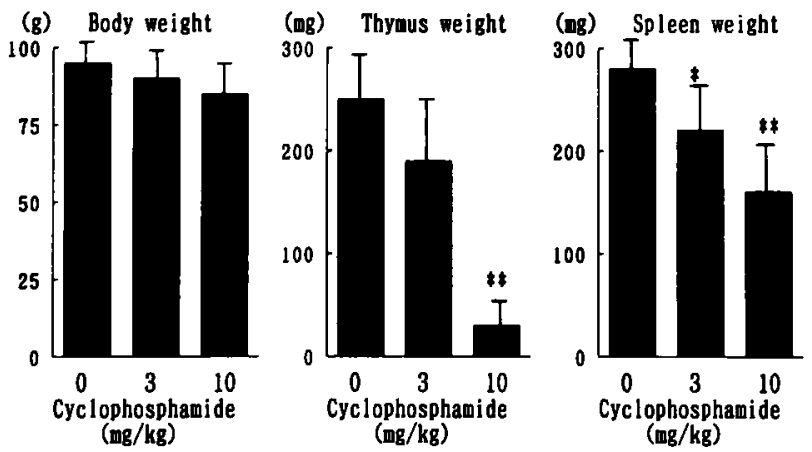

Fig. 3. Effect of cyclophosphamide on the body weight and the weights of the thymus and spleen in rats.

Cy was given intraperitoneally for 7 days.

Each column represents mean \pm SD of 5 rats.

$\mathrm{N}=5,{ }^{*} \mathrm{p}<0.05,{ }^{* *} \mathrm{p}<0.01$ vs the control 


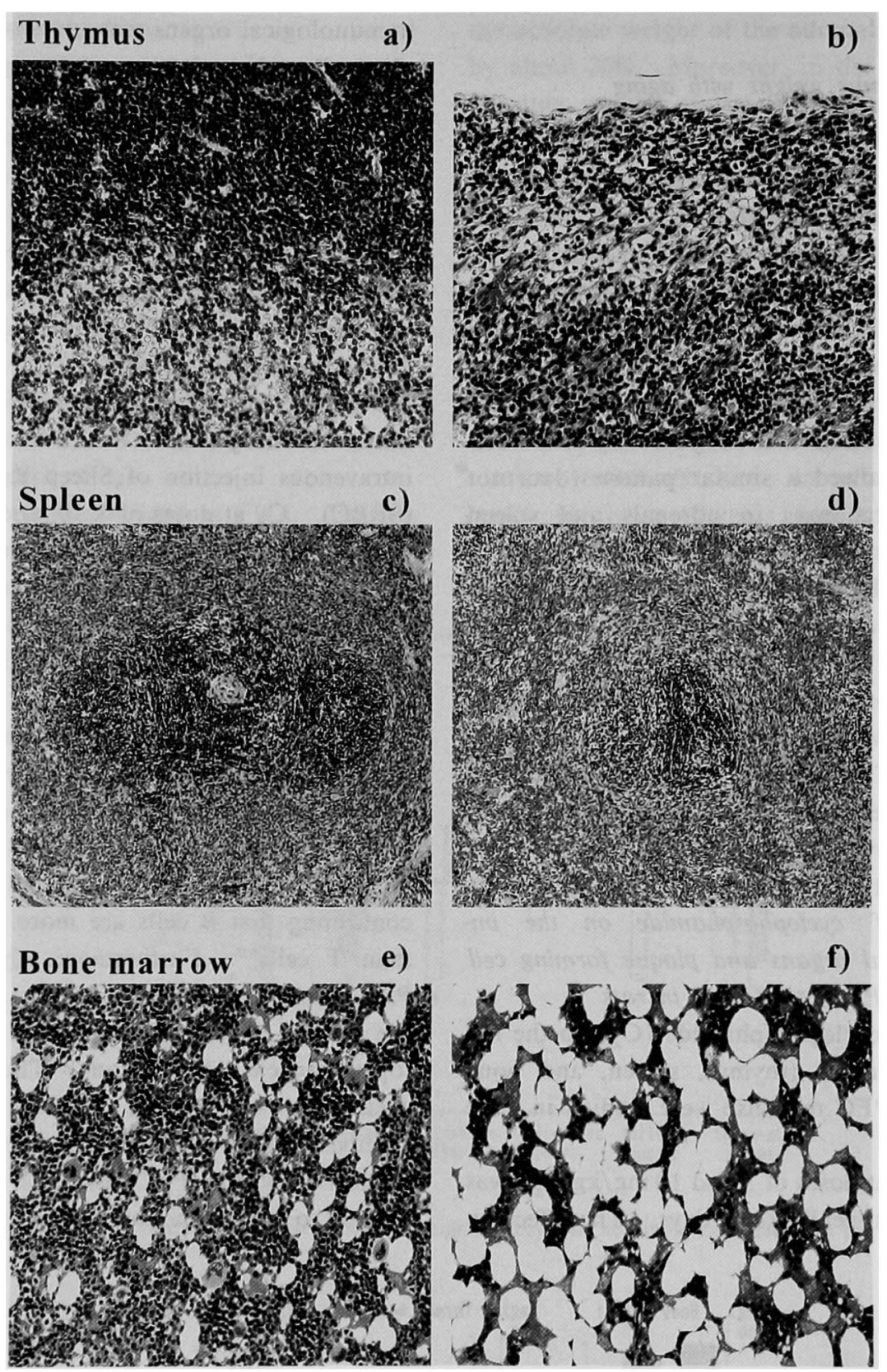

Fig. 4. The thymus, spleen, and bone marrow of a rat treated with cyclophosphamide. $\mathrm{Cy}$ at a dose of $10 \mathrm{mg} / \mathrm{kg} /$ day was given intraperitoneally for 7 days. Organ sections were stained with hematoxylin-eosin $(\times 110)$.

a, c, e : Control

b, d, f: Cyclophosphamide

Note the following observations.

Thymus, b : Atrophy of the cortex with depletion of lymphocytes

Spleen, $d$ : Atrophy of the white pulp

Bone marrow, f: Hypocellularity 
Table 3. PFC Response in Rats Treated with Cyclophosphamide

\begin{tabular}{ccc}
\hline $\begin{array}{c}\text { Dose } \\
(\mathrm{mg} / \mathrm{kg})\end{array}$ & $\begin{array}{c}\text { No. of } \\
\text { animals }\end{array}$ & $\begin{array}{c}\text { PFCs } / 10^{\circ} \\
\text { spleen cells }\end{array}$ \\
\hline 0 & 5 & $587 \pm 145^{1)}$ \\
\hline 3 & 5 & $392 \pm 126^{*}$ \\
\hline 10 & 5 & $230 \pm 50^{\circ}$ \\
\hline 30 & 4 & $6 \pm 2^{*}$
\end{tabular}

1) Mean $\pm S D$

Rats were immunized (i.v.) with $0.5 \mathrm{ml}$ of a $1 \%$ SRBC suspension and sacrificed 4 days later.

: $: \mathrm{P}<0.01$ vs the control

response. Luster reported that the splenic antibody PFC response and cell surface marker analysis are very closely related to the immunotoxicity of chemicals.

3) Capability of $T G P-3$ to induce IL-1 $\beta$ production and enhance the proliferation of eosinophils

Cytokines have various kinds of physiological actions. It is well known that cytokines can act both directly and indirectly by inducing the production of other cytokines. Recently, some cytokines such as IL-2 and IFN $\alpha$ have been used clinically, and immunological adverse effects of these drugs have been reported ${ }^{9,10}$. As TGP-3 caused fever when administered clinically, the possible involvement of IL-1 was investigated using human blood mononuclear cells (MNC) and rabbits ${ }^{11}$. As shown in Fig. 5, TGP-3 induced the production of IL- $1 \beta$ in culture extracts of MNC. Moreover, when culture extracts of MNC stimulated with TGP-3 were injected intravenously into rabbits, fever typical of an endogenous pyrogen ${ }^{12}$ was induced (Fig. 6). These results suggest that the fever induced by TGP-3 may be caused in part by the induction of IL- $1 \beta$ production. Besides, tumor necrosis factor $\alpha$, another endogenous pyrogen, was not detected in the culture supernatant (data not shown).

TGP-3 enhanced eosinophil proliferation in rats and humans ${ }^{13,14}$. Enhancement of eosinophil proliferation was observed in the hematological examination of rat receiving TGP-3 intraperitoneally for 13 weeks (Table 4). This can be explained by the involvement of cytokines such as IL-3 and IL-5 in mice ${ }^{15}$; however, this explanation may not apply to rats or humans.

\section{Other aspects of immunotoxicity}

\section{Environmental pollutants}

Various kinds of xenobiotics including polyhalogenated aromatic hydrocarbons $(2,3,7,8-$
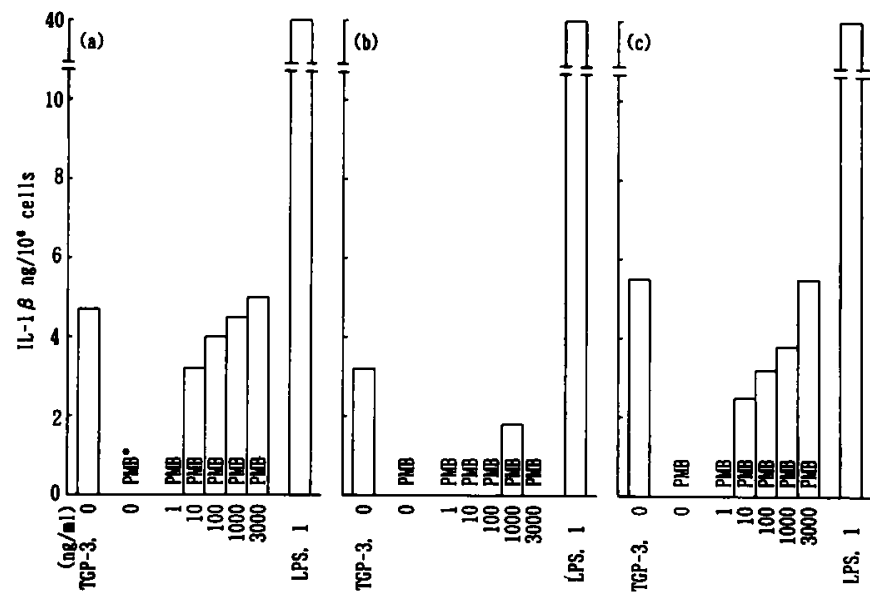

Fig. 5. Induction of IL-1 $\beta$ by TGP-3 and lipopolysaccharide (LPS) in cultures of human mononuclear cells from three donors $(a, b$, and $c)$.

Mononuclear cells $\left(5 \times 10^{5}\right)$ were incubated with TGP-3 or LPS for $24 \mathrm{hr}$ at $37^{\circ} \mathrm{C}$.

IL-1 $\beta$ was measured by a radioimmunoassay.

"PMB : polymyxin B $(5 \mu \mathrm{g} / \mathrm{ml})$

Each value represents the mean of duplicate assays. 


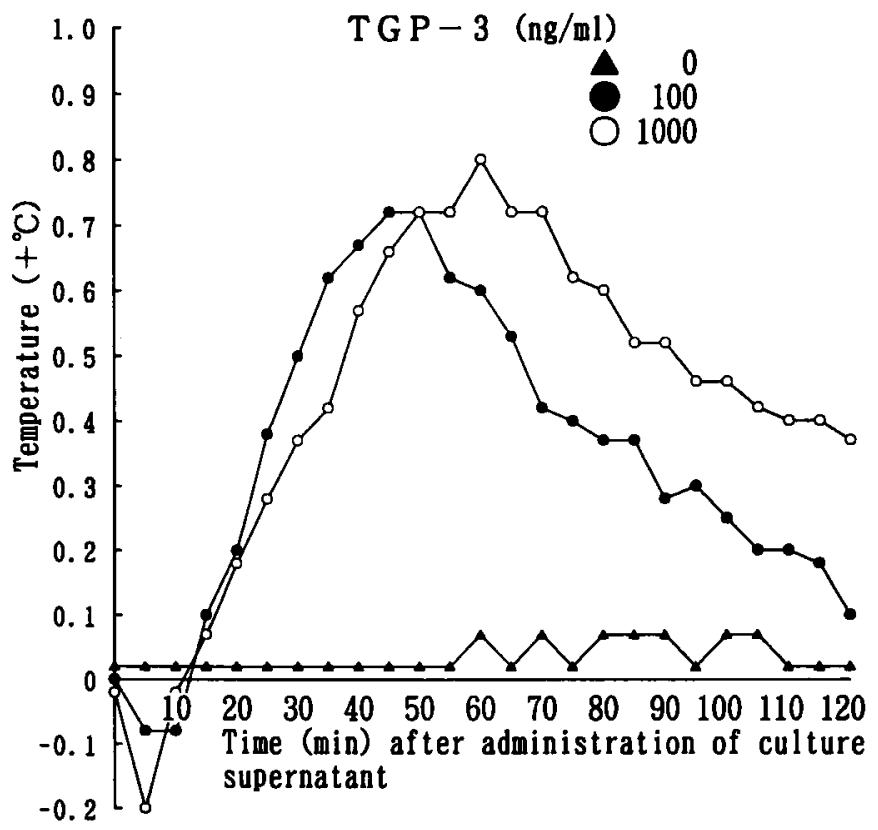

Fig. 6. Fever induced by the culture extract of human blood mononuclear cells stimulated with TGP-3. The culture extracts were given intravenously to rabbits at a dose of $10 \mathrm{ml} / \mathrm{kg}$.

The pooled culture extract from human blood mononuclear cells stimulated with TGP-3, 0, 100 and 1000 $\mathrm{ng} / \mathrm{ml}$ contained IL-1 $\beta$ of $<2.5,16.2$ and $22.3 \mathrm{ng} / \mathrm{ml}$, respectively.

Each point represents the mean of 3 rabbits.

Table 4. Hematology in a Thirteen-week Intraperitoneal Toxicity Study of Recombinant Human Interleukin 2 (TGP-3)

- Group mean values (Absolute value)-

\begin{tabular}{cccccccc}
\hline Sex & $\begin{array}{c}\text { Dose } \\
(\mu \mathrm{g} / \mathrm{kg} / \mathrm{day})\end{array}$ & $\begin{array}{c}\text { No. of } \\
\text { animals }\end{array}$ & $\begin{array}{c}\text { Neutro } \\
\text { phils }\end{array}$ & $\begin{array}{c}\text { Limpho } \\
\text { cytes }\end{array}$ & $\begin{array}{c}\text { Mono } \\
\text { cytes }\end{array}$ & $\begin{array}{c}\text { Eosino } \\
\text { phils }\end{array}$ & $\begin{array}{c}\text { Baso } \\
\text { phils }\end{array}$ \\
\hline \multirow{3}{*}{ Male } & Vehicle & 10 & $12.0 \pm 7.4$ & $43.6 \pm 13.2$ & $0.6 \pm 0.4$ & $0.8 \pm 0.5$ & $0.0 \pm 0.0$ \\
& 0.2 & 10 & $11.2 \pm 5.1$ & $46.7 \pm 8.6$ & $0.4 \pm 0.3$ & $0.9 \pm 0.4$ & $0.0 \pm 0.0$ \\
& 1.0 & 10 & $12.2 \pm 7.0$ & $50.2 \pm 12.3$ & $0.4 \pm 0.4$ & $1.3 \pm 1.0$ & $0.0 \pm 0.0$ \\
& 5.0 & 10 & $11.8 \pm 3.9$ & $52.2 \pm 14.3$ & $0.5 \pm 0.6$ & $4.3 \pm 4.8^{* *}$ & $0.0 \pm 0.0$ \\
\hline \multirow{3}{*}{ Female } & Vehicle & 10 & $5.2 \pm 1.6$ & $31.9 \pm 6.8$ & $0.2 \pm 0.2$ & $0.5 \pm 0.4$ & $0.0 \pm 0.0$ \\
& 0.2 & 10 & $4.8 \pm 2.3$ & $29.3 \pm 7.9$ & $0.2 \pm 0.2$ & $0.5 \pm 0.4$ & $0.0 \pm 0.0$ \\
& 1.0 & 10 & $5.1 \pm 2.0$ & $33.6 \pm 8.8$ & $0.2 \pm 0.2$ & $1.0 \pm 0.9$ & $0.0 \pm 0.0$ \\
& 5.0 & 10 & $6.0 \pm 1.1$ & $38.7 \pm 12.3$ & $0.5 \pm 0.4$ & $3.7 \pm 2.2 * *$ & $0.0 \pm 0.0$ \\
\hline
\end{tabular}

Mean \pm S.D.

** : Significantly different from the control $(\mathrm{p}<0.01)$

tetrachlorodibenzo-p-dioxin ; TCDD), heavy metals (lead), organotins (di-n/tri-n-octyltin (di) chloride; DOTC), and oxidant gases (air pollutants : $\mathrm{NO}_{2}, \mathrm{SO}_{2}$ and $\mathrm{O}_{3}$ ), have an adverse effect on the immune system $^{16}$. The immunosuppressive effects caused by xenobiotics are often ac- companied by increased susceptibility upon exposure to infectious agents or tumor cells. Organotins which were used as fungicides for potatoes and sugar beets have a strong immunosuppressive effect (thymus atrophy) and therefore suppress the $T$ cell-dependent immune 
Table 5. The Effects of Organotins on Various Immune Functions in Rats

\begin{tabular}{|c|c|}
\hline & Effect ${ }^{a)}$ \\
\hline \multicolumn{2}{|l|}{ Cell-mediated Immunity } \\
\hline \multicolumn{2}{|l|}{ In vivo } \\
\hline Delayed type hypersensitivity to tuberculin & $\mathbf{S}$ \\
\hline Allograft rejection & $\mathbf{S}$ \\
\hline Graft-versus-host reaction & $\mathbf{S}$ \\
\hline \multicolumn{2}{|l|}{ Ex vivo } \\
\hline \multicolumn{2}{|l|}{ Blast transformation of thymocytes and spleen cells by PHA, } \\
\hline Mixed leucocyte reaction (MLR) & $\mathbf{S}$ \\
\hline \multicolumn{2}{|l|}{ Humoral Immunity } \\
\hline \multicolumn{2}{|l|}{ In vivo } \\
\hline Thymus-dependent Ab-synthesis in response to sheep red blood & $\mathbf{S}$ \\
\hline Thymus-independent Ab-synthesis in response to LPS & NE \\
\hline \multicolumn{2}{|l|}{ Ex vivo } \\
\hline Blast transformation of spleen cells by LPS & NE \\
\hline Plaque formation against SRBC & $\mathbf{S}$ \\
\hline \multicolumn{2}{|l|}{ Nonspecific resistance } \\
\hline $\begin{array}{l}\text { NK-activity of spleen cells in response to } Y A C-1 \text { and } W / F 1 \\
\text { lymphoma cells }\end{array}$ & NE \\
\hline Carbon clearance of macrophages & NE \\
\hline
\end{tabular}

a) $\mathrm{S}$; suppressive effect

$\mathrm{NE}$; no effect

response (Table 5) ${ }^{17}$. Additionally, TCDD also causes thymus atrophy induced by apoptosis of $\mathrm{CD}^{+}{ }^{+} \mathrm{CD} 8{ }^{+}$cells $^{18}$. With regard to human health, the study of immunotoxicity of environmental chemicals is becoming a very important field.

\section{Autoimmune diseases and tumor formation}

Autoimmune diseases: Some drugs (chemicals) show antigenicity as haptens such as antibiotics and antirheumatic agents (e.g., D-penicillamine) and rarely cause various kinds of autoimmune diseases such as myasthenia gravis, pemphigus and glomerulonephritis. The mechanism of action of D-penicillamine is not clear, but there is a report that $\mathrm{D}$-penicillamine modifies substances in the body (e.g., cells) and a neoantigen which is recognized by $T$ cells is produced ${ }^{19}$. Other explanations have also been proposed ${ }^{20,21}$.

Tumor formation: Therapeutic immunosuppression to prevent rejection in transplant patients $^{22}$ and chronic exposure to polybrominated biphenyls (PBBs) cause an increased susceptibility to infectious diseases and neoplasia ${ }^{23}$. In mice, Cy enhanced tumor formation dose-dependently in mice inoculated with tumor cells (Fig. 7) ${ }^{24}$.

\section{Future remarks}

In this study, the effects of various stress factor (operations used in ordinary toxicity studies) and immunosuppressants (cyclophosphamide) on the immunological organs (thymus, spleen, and adrenals) were investigated in the rat. The results indicate that, it is important to take into account the stress caused by ordinary operations to accurately evaluate the results of a toxicity test. The results obtained using cyclophosphamide are in agreement with the findings obtained using azathioprine in the $\mathrm{rat}^{24}$. The international collaborative immunotoxicity studies were done using azathioprine $^{25}$ and cyclosporin $A^{26}$. In the reports, it is proposed that both immunosuppressants are useful to detect or evaluate the potential 


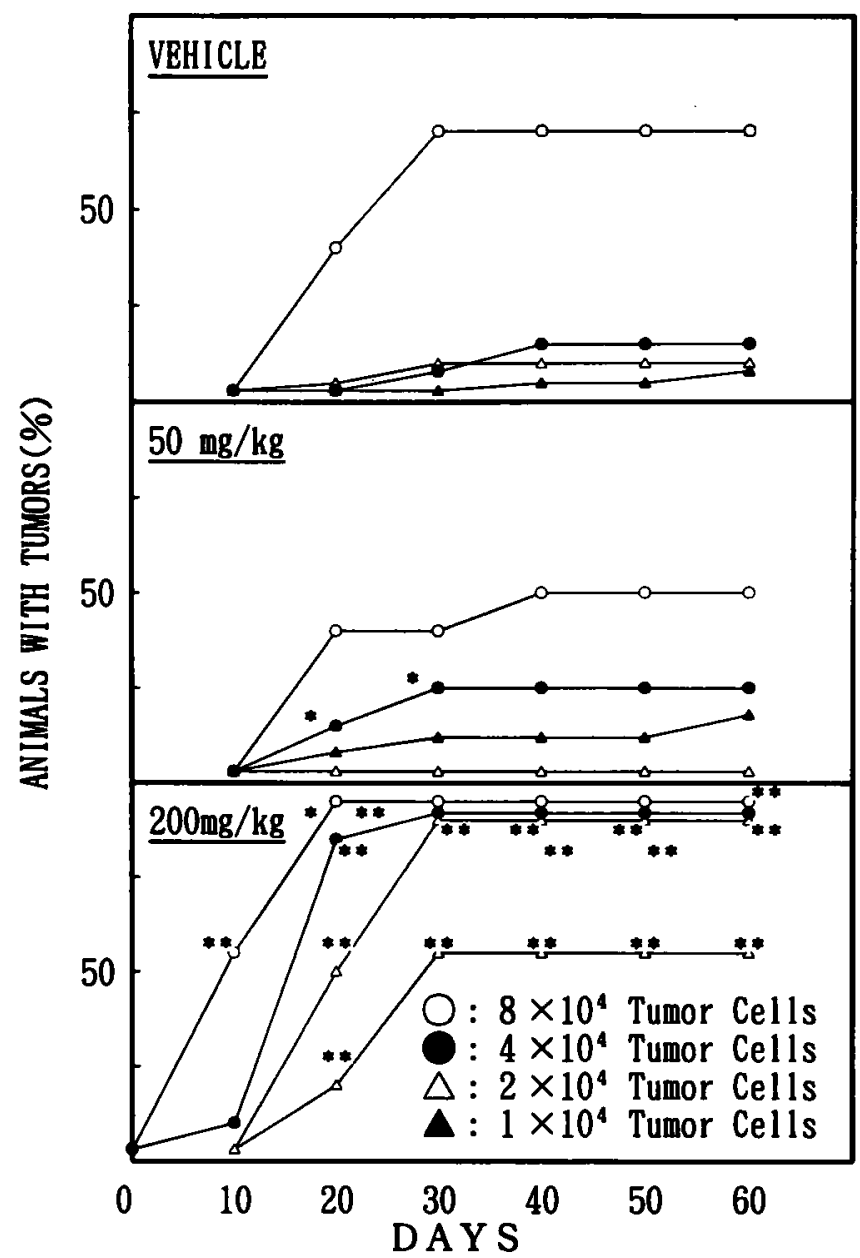

Fig. 7. Effects of cyclophosphamide on PYB6 tumor formation as a function of tumor cell challenge. Groups of mice were given a single intraperitoneal injection of saline or 50 or $200 \mathrm{mg} / \mathrm{kg}$ of cyclophosphamide followed 48 hours later by subcutaneous injection of either $1 \times 10^{4}(\Delta), 2 \times 10^{4}(\Delta), 4 \times 10^{4}(\bullet)$ or $8 \times 10^{4}(O)$ PYB6 tumor cells. The data are presented as the percent of animals that developed palpable tumors within 60 days. Each point represents 20 mice.

$*=p<0.05$ or ${ }^{*}=p<0.01$ vs the vehicle treated group by Fisher's Exact test at the same time point given equal numbers of tumor cells by Fisher's Exact test.

risk to the immune system.

Some problems and future tasks in the area of immuotoxicology are listed below.

(1) The immune system is a very complicated network comprised of many cell types (i.e., $T$ and B lymphocytes, macrophages, granulocytes, and natural killer cells with a variety of functions). Immunology is progressing rapidly and the way in which the results are introduced into the field of immunotoxicology is very important.

(2) It is necessary to take into account the facts such as the heterogeneity of the human population, outbred and wildlife when extrapolating the results obtained in animals to humans. There are some differences in individual sensitivity and response to xenobiotics and immunotoxicity tests. Moreover, certain immune functions may be influenced by additional exposure as well as unfavorable habits and life styles, for example, malnutrition, allergies, drug and alcohol consumption, smoking, and mental or physical stress.

(3) It is important to select suitable species, experimental animals (healthy, disease models, knockout mouse, transgenic mouse, and SCID mouse, etc.) and test systems for the evaluation of the immunotoxicity of xenobiotics. Furthermore, 
there will be necessary differences in the assay systems for therapeutics and for environmental pollutants.

(4) Harmonization among Japan, Europe, and the USA to standardize or validate techniques and statistical methods for the evaluation of experimental results should be achieved in the near future.

Acknowledgements: We gratefully acknowledge Messrs. Y. Ishimura, Y. Yasuhara, and J.A. Hogan for their help in preparing this manuscript.

\section{Reference}

1. Luster, MI, Munson, AE, Thomas, PT, Holsapple, MP, Fenters, JD, White, KL, Jr, Lauer, LD, Germolec, DR, Rosenthal, GJ, and Dean, JH : Methods evaluation. Development of a testing battery to assess chemical-induced immunotoxicity : National Toxicology Program's guidelines for immunotoxicity evaluation in mine. Fund Appl Toxicol 10 : 2-19, 1988.

2. Kuper, CF, Beems, RB, and Hollanders, VMH : Development and aging, thymus, rat. In Monographs on Pathology of Laboratory Animals, Hemopoietic System, Jones, TC, Ward, JM, Mohr, U, and Hunt, RD Eds, pp. 257-263, Springer-Verlag, Berlin, 1990.

3. Chiodi, $\mathbf{H}$ : The relationship between the thymus and the sexual organs. Endocrinology 26: 107 $116,1940$.

4. Doi, T, Nakai, $Y$, Yamamoto $M$, and Ando, $T$ : Appropriate conditions for the plaque forming cell (PFC) assay in rats and effects of cyclophosphamide on PFC response. J Toxicol Sci 17 : 225-233, 1992.

5. Cunningham, AJ and Szenberg, A : Further improvements in the plaque technique for detecting single antibody-forming cells. Immunology 14: 599-601, 1968.

6. Turk, JL and Poulter, LW : Selective depletion of lymphoid tissue by cyclophosphamide. Clin Exp Immunol 10 : 285-296, 1972.

7. El-Sady, E, Parker, D, and Turk, JL : The effect of cyclophosphamide in vivo on the expression of lymphocyte markers, detected by monoclonal antibodies, in the rat. Int J Immunopharmacol 8 : $961-$ 966, 1986.

8. Luster, MI, Portier, C, Pait, DG, White, KL, Jr, Gennings, C, Munson, AE, and Rosenthal, GJ : Risk assessment in immunotoxicology 1 . sensitivity and predictability of immune tests. Fund Appl Toxicol 18 : 200-210, 1992.

9. Burman, P, Karlsson, FA, Öberg, K, and Alm, G : Autoimmune thyroid disease in interferon-treated patients. Lancet 2: 100-101, 1985.

10. Machold, KP and Smolen, JS : Interferon- $\gamma$ in- duced exacerbation of systemic lupus erythematosus. J Rheumatol 17 : 831-832, 1990.

11. Saijo, $T$ and Naruo, $K$ : Mechanism of induction of fever by TGP-3 (recombinant human interleukin 2) : possible involvement of interleukin $1 \beta$ (in Japanese). Jpn J Inflam 9 : 391-395, 1989.

12. Dinarello, CA : Interleukins, tumor necrosis factors (cachectin), and interferons as endogenous pyrogens and mediators of fever. Lymphokines 14: 1-31, 1987.

13. Miyajima, H, Ando, T, Ito T, Chiba, S, and Suhara, I : Thirteen-week intraperitoneal toxicity study of recombinant human interleukin-2 (TGP-3) in rats (in Japanese). Clin Rep 23 : 4079-4098, 1989.

14. Lotze, MT, Robb, RJ, Sharrow, SO, Frana, LW, and Rosenberg, SA : Systemic administration of interleukin-2 in humans. J Biol Responce Mod 3 : 475482, 1984.

15. Takenaka, $\mathrm{T}$, Nakamine, $\mathrm{H}$, and Maeda, $\mathrm{J}$ : Effect of recombinant human interleukin-2 (TGP-3) on eosinophil response and IgE production in mice (in Japanese). Clin Rep 23 : 231-237, 1989.

16. Luster, MI, Ackermann, MF, Germolec, DR, and Rosenthal, GJ : Perturbations of the immune systen by xenobiotics. Environ Health Persp 81 : 157$162,1989$.

17. Penninks, AH, Pieters, RHH, Snoeij, NJ, and Seinen, W: Organotin-induced thymus atrophy. Thymus Update 91 : 57-79, 1991.

18. Hiramine, C, Koseto, M, Nakagawa, T, and Hojo, $\mathrm{K}$ : Enhancement of apoptotic cell death in mouse thymocytes by $2,3,7,8$-tetrachlorodibenzo-p-dioxin (TCDD) in vivo and in vitro (in Japanese). Environ Sci 5 : 211-218, 1992.

19. Nagata, N, Hurtenbach, U, and Gleichmann, E : Specific sensitization of lyt-1+2-T cells to spleen cells modified by the drug $\mathrm{D}$-penicillamine or a stereoisomer. J Immunol 136 : 136-142, 1986.

20. Tournade, H, Pelletier, L, Pasquier, R, Vial, M-C, Mandet, C, and Druet, P : D-penicillamine-induced autoimmunity in Brown-Norway rats. Similarities with $\mathrm{HgCl}_{2}$-induced autoimmunity. J Immunol 144: 2985-2991, 1990.

21. Gleichmann, E, Pals, ST, Rolink, AG, Radaszkiewicz, $\mathrm{T}$, and Gleichmann, $\mathrm{H}$ : Graftversus-host reactions: clues to the etiopathology of a spectrum of immunological diseases. Immunol Today 5 : 324-332, 1984.

22. Penn, I : Neoplastic cosequences of immunosuppression. In : Immunotoxicology and Immunopharmacology and Dean. JH, Luster, MI, Munson, AE, and Amos, H Eds, pp. 79-89, Raven Press, New York, 1985.

23. Bekesi, JG, Holland, JF, Anderson, HA, Fischbein, AS, Wolfe, HA, and Selikoff, IJ, : Lymphocyte function of Michigan dairy farmers exposed to polybrominated biphenyls. Science 199: 1207-1209, 1978.

24. Luster, MI, Portier, C, Pait, DG, Rosenthal, GJ, Germolec, DR, Corsini, E, Blaylock, BL, Pollock, P, Kouchi, Y, Craig, W, White, KL, Munson, AE, and 
Comment, CE : Risk assessment in immunotoxicology II. Relationships between immune and host resistance tests. Fundam Appl Toxicol 21 : 71-82, 1993.

25. Matsumoto, K, Sekita, K, Ochiai, T, Takagi, A, Takada, K, Furuya, T, Kurokawa, Y, Saito, Y, Teshima, R, Suzuki, K, Sawada, J, Terao, T, and Tobe, $\mathbf{M}$ : Evaluation of immunotoxicity testings using azathioprine-treated rats: The international collaborative immunotoxicity study (azathioprine) (in Japanese). Bull Natl Inst Health Sci 108 : 3439, 1990.

26. Ochiai, T, Naito, K, Murakami, O, Ohno, K, Sekita, K, Furuya, T, Kurokawa, Y, Matsumoto, K, Saito, Y, Hachisuka, A, Teshima, R, Yamazaki, T, Ikebuch, H, and Sawada, J : Evaluation of immunotoxicity tests using cyclosporin A- treated rats : The international collaborative immunotoxicity study II (cyclosporin A) (in Japanese). ibid 111 : 91-99, 1993. 